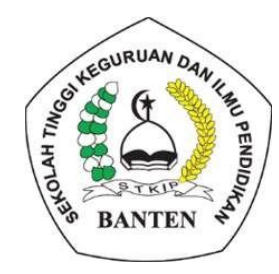

Tulip 10 (2) (2021) : 101-109 http://journal.stkipbanten.ac.id/index.php/tulip

\title{
THE IMPLEMENTATION OF MIND MAPPING STRATEGY ON STUDENTS'SPEAKING ABILITY (LITERATURE STUDY)
}

\author{
Ahmad Yanuar Syauki ${ }^{1}$, Bendra wardana ${ }^{2}$, Sulistiawati Maulina ${ }^{3}$ \\ ${ }^{1}$ Banten High School Of teacher And education \\ ${ }^{2}$ Banten High School Of teacher And education \\ ${ }^{3}$ English Education Student \\ Email: aysyauki@yahoo.com ${ }^{1}$, benracounselor@gmail.com ${ }^{2}$, \\ $\underline{\text { sulistiawatimaulina@gmail.com }}{ }^{3}$ \\ Artikel: \\ Literature Study Article Implementation Of Mind Mapping Strategy On Speaking \\ Penerima: Juli, 2021 Diterima: Agustus, 2021 Dipublikasikan: September, 2021
}

\begin{abstract}
This objective of the study is to improve students' speaking skills through the implementation of the mind mapping strategy. This study uses a literature study consisting of several sources, such as primary sources from books and secondary sources from manuscripts and journals. The results of the research that the author did from several sources studied by Asrifal Mirza increased the score which post-test experiment was higher (mean 69.05) while the mean of post-test control class was 57.11. Researcher tati rahmawati on his journal So it can be seen from the result of the first cycle, in this test we can know that the highest score was 88, the lowest score was 56 and the average of students' score was 71.7, for the second cycle the highest score was 100, the lowest score was 76 and the average of the students' score was 8o.9. It showed that there was significant improvement of students' skills in speaking. And from the overall results of previous studies that examined theoretically, it can be concluded that the implementation of mind mapping strategy had a significant effect.
\end{abstract}

Key Words: Implementation of mind mapping, Speaking english

\section{INTRODUCTION}

Speaking is a language skill that develops in a child's life, which is only preceded by listening skills, and at that time the ability to speak or speak is learned. The people in this world speak many languages. From all of the language in the world English in the most used. It is international language and millions of the people now speak English. During such activities, we communicate by using oral language or speaking that makes possible to convey our message, information, and expectation to other people. The writer assumes that speaking is essential thing in our daily life because, it has many advantages such as building social interaction misunderstanding, reducing and sharing the information. From the advantages above, speaking ability is significant to be analyzed and this research focus on Mind Mapping strategy in learning English. 
2 Ahmad yanuar Syauki1, Bendra Wardana2, dan sulistiawati Maulina3. The Implementation of Mind Mapping Strategy on Students' Speaking Ability.

To success the teaching for improving the students to speak English in a second language classroom, there is a material for speaking practice created by the writer namely mind mapping strategy, and the mind mapping diagram used to represent words, ideas, tasks, or other items linked to and arranged around a central key word or idea. In some previous studies that students were, most of the time, anxious in speaking and some of them preferred to sit at the corner of the class or pretending to be sick to avoid a chance to speak in front of the class, they have no ideas to speak in public, loss of confidence and motivation in learning speaking English.

To overcome these problems, it is necessary to hold a strategy that can improve students' speaking. One alternative to solve this problem is to carry out learning using a mind mapping strategy. Mind mapping is very appropriate to overcome these problems. Because the mind mapping can help students get to know and follow the material correctly. By using mind mapping, students are more likely to be active and feel unsaturated, because in essence the world of school is the world of children or the world of play.

\section{THERITICAL FRAME WORK \\ 1. Definition of Mind Mapping}

Mind mapping is a technique of utilizing the whole brain by using visual images and other graphic infrastructure to form impressions. The brain often remembers information in the form of images, symbols, sounds, shapes and feelings. Mind maps use these visual and sensory reminders in a pattern of related ideas such as road maps used for learning, organizing, and planning.

Buzan opined that mind mapping is a diagram used to represent words, ideas, tasks, or other items linked to and arranged in radial around a central key word or idea. It is used to generate, visualize, organize, and classify ideas. It is an image-centered diagram that represents meaning or other connections between portions of information. These maps can generate original ideas and trigger easy memories. This is much easier than traditional notetaking methods because it activates both hemispheres of the brain. This method is also calming, fun, and creative. Furthermore, mind-map graphically show ideas in a relational framework, with the main topic at the center of the paper, major subtopics on branches derive from the main topic, and sub-subtopics around each major sub- topic.

The use of concept maps is considered to have a significant effect during the pandemic and post-pandemic periods such as Covid-19. Concept maps can also make learning easier. This is because it displays learning material with attractive visuals and is interconnected between concepts so that it can be seen that they are related Yuniati, 2013. The use of concept maps balanced with explanatory material can be used as an option for distance learning.

In order to create a mind-map, people usually start in the middle of the page to draw the central theme or main idea. Then, draw wider in all directions to create a growing diagram composed of keywords, concepts, facts, and information. Furthermore, mind-map graphically show ideas in a relational framework, with the main topic at the center of the paper, major subtopics on branches derive from the main topic, and sub-subtopics around each major sub- topic. Mind map can be created using paper and pens or using one of several computer applications.

\section{Characteristics of mind mapping}

1. Each mind-map has a central picture as a starting location containing the main theme or idea.

2. The ideas of the mind-map "released" from the central topic or image as branches with sub-topics connected to each other.

3. The final structure of the mind-map becomes a hierarchy of linked ideas. 
4. Each branch has keywords or colorful pictures connected to each other. It is recommended to use the picture in the entire mind-map.

Here is an illustration of a concept map by Buzan (Brandner, 2019).

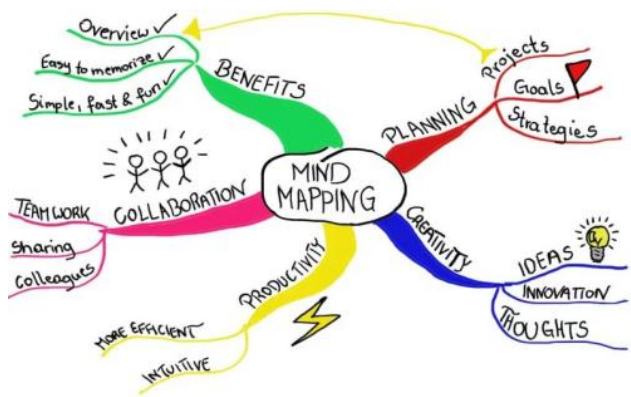

Picture 1.1 Ilustration of

concept map by tony buzan

source, https://www.mindmeister

.com/blog/tony-buzan-tributel

\section{The Advantages of Mind Mapping}

* They automatically inspire interest in the student, thus making them more receptive and co-operative in the classroom.

* They make lessons and presentation more spontaneous, creative and enjoyable, both for the teacher and the students.

* Rather than remaining relatively rigid as the years go by, the teacher's notes are flexible and adaptable. In these times of rapid change and development, the teacher need to be able to alter and add to teaching notes quickly and easily.

* Because mind maps present only relevant material in a clear an memorable form, the student tend to get better marks in examinations.

* Unlike linear text, mind map show not just the fact but the relationships between those facts, thus giving the student a depper understanding of the subject.The physical volume of lecture notes dramatically reduced.

\section{Indicators of The Mind Mapping Strategy}

According to Tony Buzan the Mind

Mapping indicators are as follows:
a. Plan
b. Communicate
c. To be More Creative
d. Remember Better
e. Solve The Problem
f. Focus Attention
g. Compose and Explain Thoughts
h. Learn Faster and More efficiently, and
i. Train The "Whole Picture"

\section{Definition of Speaking}

Speaking is one of four important abilities in English, especially when the speakers are not from English native country. The ability is described as the capability to use language in real situation, the ability to report acts in precise words, or the ability to express or converse ideas fluently. Speaking is a tool of communication in conveying ideas, information, and feeling to others. It is the most important way for a speaker to express himself through a language Bashrin quoted from Ur said that "Speaking is the productive aural/oral skill. It consists of producing systematic verbal utterance to convey meaning. Speaking is the way of communicating ideas and messages orally. If we want to encourage students to communicate in English, we should use the language in real communication and ask them to do the same process. Boonkit opined that speaking is one of four important skills in learning English, especially when the speakers are not from English native. Furthermore, it is essential for EFL students to improve their speaking ability together with other ability in order to achieve communication goal.every of acquiring knowledge and developing ability to communicate with people.

Speaking is one of four important abilities in English, especially when the speakers are not from English native 
4 Ahmad yanuar Syauki1, Bendra Wardana2, dan sulistiawati Maulina3. The Implementation of Mind Mapping Strategy on Students' Speaking Ability.

country. The ability is described as the capability to use language in real situation, the ability to report acts in precise words, or the ability to express or converse ideas fluently. English as Foreign Language (EFL) student should improve their speaking ability since English has become the first international language that use to communicate with people from all around the world. English speaking ability should be improved together with the other abilities in English to fulfill the communication requirements.

Tarigan said that: Speaking is the ability to utter articulate sounds or words to express, express and communicate thoughts, ideas, and feelings. The main purpose of speaking is to communicate. Communication can unite individuals into groups by way convey the general concepts, creating a unity of symbols that distinguish it from other groups, and assign an action, and will not survive long if not societies language. Speaking language is a skill that develops in the child's life, which only preceded by listening skills, and on the ability to speak or say.

\section{The Importance of Speaking}

It is important to understand that the improvement of spoken language is not only learning skills such as pronouncing English sounds or the ability to produce single utterances or phrases but also the development of spoken language is an ongoing and a difficult process in social life. Pourhosein Gilakjani expressed that speaking is of great significance for the people interaction where they speak everywhere and day.

Speaking is the way of communicating ideas and messages orally. If we want to encourage students to communicate in English, we should use the language in real communication and ask them to do the same process. Boonkit opined that speaking is one of four important skills in learning English, especially when the speakers are not from
English native. Furthermore, it is essential for EFL students to improve their speaking ability together with other ability in order to achieve communication goal.every of acquiring knowledge and developing ability to communicate with people.

\section{Assessing Speaking}

According to oxford dictionary assessing is a carefully considered opinion or judgment. In addition, Assessment is a process of activities to find out whether a predetermined program works well or unwell.In assessing speaking skill there are five assessments are:
a. Fluency
b. Pronunciation
c. Vocabulary
d. Accuracy
e. Interaction
f. Communication

How to Develop Students' Speaking Ability

To facilitate the ability to speak (speaking), below will be explained some ways / methods that are quite useful for us to try. Among others are:
a. Expand Vocabulary (vocabulary)
b. Reading Aloud
c. Know Simple English Grammar
d. Reading English Writing
e. English conversation
f. Listening to English songs
g. Watching English Films
h. Happy To Learn English

\section{METHODE OF RESEARCH}

This research is a form of literature study research. According to Suarifqi Diantama, Literature study is carried out by studying and reviewing books that are related to the problem under study to obtain materials or sources of information about the problem under study Researchers in conducting studies explore various available literature, whether in the form of books, journals, papers, articles, and research reports. In addition, researchers also conducted interviews with teacher as 
an additional source. The research used is literature research with a qualitative descriptive approach.

\section{THE RESULT OF RESEARCH AND DISSCUSSION}

In this section, the author describes the general description of the research location related to students, the profile of schools, institutions, institutions that are the object of the author's research. In addition, it will also describe the description of the library sources used in this study, which consist of primary and secondary sources.Primary library sources are libraries that are used as the core information data of this research such as books, journals, theses and research results related to the implementation of mind mapping strategy on students' speaking ability. While secondary libraries are library materials that are used as supporting data.

\section{Result of The Research}

Based on Asrifal Mirza (2016) in his thesis research entitled The Use of Mind Mapping strategy to Improve students' Ability The result of the implementation of mind mapping strategy to improve students' speaking ability, the average experimental class is 69.05 and control class 57.11 .

Based on Tati Rahmawati (2018) in his thesis research entitled The Implementation of mind Mapping Technique to Improve Students' Speaking Skills at the seventh grade students of MTs At-Toyibah Curuglemo The results of the improvement of the implementation of mind mapping technique to improve students' speaking skills can be seen from the average test results of the first and second cycles.the first cycle the average value of students' the the lowest score was 56 for the second cycle the highest score was 100, the lowest score was 76 and the average of the students' score was 80,9. Researchers analyze the implementation of

(C) 2021, Tulip, Jurnal Tulisan Ilmiah Pendidikan. STKIPB e-ISSN: $2807-4114$ mind mapping will be more fun and make learning speaking easier to learn.

Rahmat Syawaludin\& sutama (2018) in their journal entitle is Penggunaan Peta Konsep Mempermudah Belajar Siswa Selama Masa Pandemi Covid-19 the result of the research that are During this pandemic the use of concept maps can be an option for distance learning. The effective way is accompanied by a little supporting material in the form of a clear outline and or description. A clear description will avoid differences in the perceptions of students and teachers. The use of concept maps has been proven to have an impact on making it easier for students to learn. Also effective in improving student academic achievement. Using concept maps can also improve students' critical thinking skills. Its use is not only limited to elementary school students, but can also be used by college students. Using concept maps can also lead to active interaction between teachers and students.

Nurlaila A.p (2013) the result of the research showed that there was an improvement in the students' writing descriptive text after being taught using mind mapping. Based on the result presented before, it is proven that there was an improvement of students' writing ability in term of content, organization, vocabulary, grammar, and mechanics. The aspect of writing that improved the most was content. It can be seen from the comparison of mean score of pretest and posttest. The pre-test average score was 53.23 and in the posttest average score was 63.33. It could be seen that there was improvement 10.10 or $18.97 \%$ in the posttest average score.

In this chapter, research results show that there is an increase in students' speaking learning outcomes using a mind mapping strategy, it can be seen from the results of some of the literature analyzed from the four primary data showing a significant increase, so learning using a 
6 Ahmad yanuar Syauki1, Bendra Wardana2, dan sulistiawati Maulina3. The Implementation of Mind Mapping Strategy on Students' Speaking Ability.

mind mapping strategy can improve results students' learning.

\section{DISSCUSSION}

According to Asrifal Mirza (2016) in his thesis research entitled The Use of Mind Mapping strategy to Improve students' Ability researchers conducted research on the background of problem which is observation to students of Madrasah Aliyah Swasta (MAS) Darul Ihsan Aceh Besar shown that students were, most of the time, anxious in speaking and some of them preferred to sit at the corner of the class or pretending to be sick to avoid a chance to speak in front of the class, they have no ideas to speak in public, loss confidence and motivation in learning speaking English.

English speaking ability is very important for people interaction where people almost speak everywhere and every day through English. In this global era, many people used English as a media of communication and it makes people who come from different countries to be easier in making interaction and communication. Mind mapping is one of many strategies in teaching and learning English. Many teachers use this teaching strategy to teach writing, reading, and speaking. This strategy will facilitate the students to speak or present their thought in front of class easly .

The result of the implementation of mind mapping strategy to improve students' speaking ability, the average experimental class is 69.05 and control class 57.11 . The researcher analyzes that the use of mind mapping strategy is very effective in increasing student interest and the results are very significant, we can see from the quasi-experimental results, the increase in the students' pre-test and posttest results and the interviews that have been conducted.

Tati Rahmawati (2018) in his thesis research entitled The Implementation of mind Mapping Technique to Improve

(C) 2021, Tulip, Jurnal Tulisan Ilmiah Pendidikan. STKIPB e-ISSN: $2807-4114$
Students' Speaking Skills at the seventh grade students of MTs At-Toyibah Curuglemo.stated that before using mind mapping strategy Students speaking skills at MTs At-Toyibah are still low, the students vocabularies are low and less understanding in word meaning, they find it hard to practice their speaking even though the teacher has taken other approaches and methods: Method lectures, questions and answers, exercises, but the author sees that not all students are active in participating in the English learning process in the standard process of students' speaking competence.

The results achieved have not been maximized, because of some of the problems that have been described. Teacher also must understand the situation and condition of their students in the class and the students' problem in mastering speaking skill. Based on the research in seventh grade of At-toyibah junior high school, most of the students had no courage to speak, lack of vocabulary, and have no encouragement to learn English especially in speaking ability. In this case the author overcomes this problem using mind mapping techniques in his learning.

The results of the improvement of the implementation of mind mapping technique to improve students' speaking skills can be seen from the average test results of the first and second cycles the first cycle the average value of students' the the lowest score was 56 for the second cycle the highest score was 100, the lowest score was 76 and the average of the students' score was 80,9. Researchers analyze the implementation of mind mapping will be more fun and make learning speaking easier to learn.

According to Rahmat Syawaludin (2018) in their journal entitle is Penggunaan Peta Konsep Mempermudah Belajar Siswa Selama Masa Pandemi Covid-19 The current Covid-19 pandemic threatens the safety of the world. Several countries are starting to make adjustments 
to deal with this Covid-19 pandemic. Seeing such conditions, teachers should not burden students with heavy and many tasks. Learning activities should be emphasized by providing material that is efficient and does not burden students.

One way is to use concept maps to convey the material. Each teacher has their own strategy to use in their classroom during this distance learning. If explored more deeply, there is a strategy where teachers can provide material in depth without having to harm students who are constrained by internet access. The strategy is to use a concept map. The use of concept maps is considered to have a significant effect during the pandemic and post-pandemic periods such as Covid-19. Concept maps can also make learning easier. This is because it displays learning material with attractive visuals and is interconnected between concepts so that the relationship is visible .

Researchers analyze the implementation of mind mapping will be more creative and can improve students' speaking ability. The results of the increase can be seen from the conclusions of several literatures. During this pandemic the use of concept maps can be an option for distance learning.The effective way is accompanied by a little supporting material in the form of a clear outline and or description. A clear description will avoid differences in the perceptions of students and teachers.

The use of concept maps has been proven to have an impact on making it easier for students to learn. Also effective in improving student academic achievement. Using concept maps can also improve students' critical thinking skills. Its use is not only limited to elementary school students, but can also be used by college students. Using concept maps can also lead to active interaction between teachers and students.

According to Nurlaila A.p (2013) in his thesis research entitled The Use of Mind Mapping Technique in Writing Descriptive Text this research will discuss the result of a study on the effectiveness of mind mapping technique in teaching writing Descriptive texts to seventh-graders in a Junior High School in Bandung. This research was taken because students' understanding of descriptive text is still low because the method used by the teacher is still classical, namely the teacher stands in front of the class with a blackboard and markers as the medium, so that students just sit neatly in their respective places.

They believe that mind mapping can balance the brain, help to organize thoughts, improve the creativity, speed of learning and memory and is based on state psychologists that mind mapping is a type of prewriting method as the first stage of the writing process and as the point at to discover and exploreour initial ideas about a subject. Prewriting helps us to get our ideas on paper, though not usually in an organized form, and brainstorm thoughts that might eventually make their way into our writin. Some people, including students who claim writing is difficult may have a difficulty in terms of expressing their ideas into a paper so that they have to search a keyword first. Mind mapping can become the way to solve this problem. In applying this technique, teachers can ask the students to make a mind map before they write to stimulate students' mind and give some ideas in form of outline, so, students can see their outline when they start to write.

The first the result of the implementation of mind mapping strategy to improve students' speaking ability, the the lowest score was 56 for the second cycle the highest score was 100 , the lowest score was 76 and the average of the students' scores. So the researcher analyze that mind mapping technique was effective to help students in writing Descriptive texts in an enjoyable way.

Based on the explanation above it can be stated the implementation of mind mapping strategy can improve students' 
8 Ahmad yanuar Syauki1, Bendra Wardana2, dan sulistiawati Maulina3. The Implementation of Mind Mapping Strategy on Students' Speaking Ability.

speaking ability can be seen from indicators.

\section{CONCLUSSION}

Based on the description of the results of research that has been carried out by researchers using literature methodology, from various primary and secondary sources of research that have been collected, it can be concluded that the implementation of mind mapping strategy can potentially improve students' speaking learning. This can be seen from the average value of the use of mind mapping from the four primary data that has been examined, all four of which have increased in each cycle, from this influence, this is motivated by learning in the form of mind mapping, it allows the learning process to run more fun, because it is a learning strategy. which in its implementation by playing with pictures that are interesting, creative, but they are also learning while learning.

\section{SUGGESTION}

\section{For Teacher}

The researcher offers suggestions for using mind mapping strategy to improve students' speaking skills, because based on the research results, this strategy is effective for improving students' speaking skills.

English teachers should learn more how to improve their skills in teaching English and build a good atmosphere in the classroom, so that students feel happy and enthusiastic in learning English.

Teachers must be familiar with various strategies or teaching strategy that can improve students' speaking skills.

\section{For the Next Researche}

For other researchers, it is hoped that the results of this study can be used as a reference for conducting better research by using learning using the implementation of mind mapping strategy to further improve learning in English.

\section{REFERENCES}

Bashirin,S.D.(2013).Productive Skills:Teaching Beginners in English Medium School,Bangladesh:BRAC University

Diantama, Suarifqi. (2018). "Metode Penelitian Pendidikan". Bandung: Pustaka Rahmat.

Henry,GunturTarigan,(2015).“BerbicaraS ebagaiSuatuketerampilanBerbahasa, Bandung”, PercetakanAngkasa.

Mirza, Asrifal.(2016)," The Implementation of Mind Mapping Strategy to Improve Students' Speaking Ability". Faculty of tarbiyah and Teacher Training Islamic State University of ARRainy Darussalam: Banda aceh. From:

https://www.google.co.id/url?q=http s://repository.arraniry.ac.id/826/1/as rifal\%2520mirza.pdf\&sa=U\&ved $=2$ ahUKEwift9nnpXxAhUG63MBHWO CC48QFjABegQICBAB\&usg $=A O v V$ aw0MDIrsqYHb9BmDipZCCodI

Nurlaila, A. P. (2013). The use of mind mapping technique in writing descriptive text. Journal of English and Education, 1(2), 915..https://ejournal.upi.edu/index.ph p/L-E/article/view/578/435

$\begin{array}{lrr}\text { Rahmat , S \& } & \text { Sutama } & \text { (2020) } \\ \text { Penggunaan } & \text { Peta } & \text { Konsep } \\ \text { Mempermudah } & \text { Belajar } & \text { Siswa } \\ \text { Selama Masa Pandemi } & \text {.Universitas } \\ \text { Muhammadiyah } & \text { Surakarta. } \\ \text { Surakarta. } & \\ \text { https://www.google.co.id/url?q=http: } \\ \text { //journals.ums.ac.id/index.php/jmp/ar } \\ \text { ticle/download/11279/6206\&sa=U\& } \\ \text { ved=2ahUKEwi5n6vV1ubxAhUC5n } \\ \text { MBHV1fCksQFjABegQIABAB\&us }\end{array}$


$\mathrm{g}=\mathrm{AO}$ VVaw3zMsM0YsZxlpmbc44x $\mathrm{P}-\mathrm{B} 5$

Rahmawati, Tati.(2018)," The Implementation of Mind Mapping technique to Improve Students' Speaking Skills".Universitas Islam Negri'SMH"Banten.From:https://w ww.google.co.id/url?q=http://reposit ory.uinbanten.ac.id/3027/\&sa=U\&ve $\mathrm{d}=2$ ahUKEwift9nnpXxAhUG63MB HW0CC48QFjAAegQICRAB\&usg= AOvVaw1zSFsJEU6B5CWBVe2bk $\mathrm{xB} 7$

Rao. Parupally Srinivas.(2019). The Important of Speaking Skillsin English Language Center. AlHasa:Kingdom of Saudi Arabia 